Table 1. Geographical Distribution of Diploid Numbers in Prentatomidae

\begin{tabular}{|c|c|c|c|}
\hline & $2 n=14$ & $2 n \neq 14$ & Total \\
\hline $\begin{array}{l}\text { Tropical and sub- } \\
\text { tropical spp. } \\
\text { Temperate spp. }\end{array}$ & $\begin{array}{l}40 \\
58\end{array}$ & $\underset{19}{2}$ & $\begin{array}{l}42 \\
77\end{array}$ \\
\hline Total & 98 & 21 & 119 \\
\hline
\end{tabular}

higher systematics of the superfamily. Applying a new classification of Pentatomoidea (unpublished) and deleting species of doubtful determination or uncertain provenance, there remain 119 cytologically known Pentatomidae sensu stricto : these may be grouped as in Table 1. The ancestral diploid or type number, which here happens to coincide with the modal number, is $14 ; 12 A+X+Y$ in males.

Inspection of Table 1 shows a statistically significant $(P=0.029)$ association of atypical caryotypes with a temperate climate. The systematic positions of the atypical species and the presence of genera with a Thyanta-like range and caryotype pattern show that the association is not with a Holarctic distribution or monophyletic block although all the temperate forms so far examined live in the Palæarctic or Nearctic.

The present facts suggest either that: (1) rearrangements accompanying speciation in temperate climates tend, under the influence of some external factor, to be more often associated with gross caryotype changes than is the case in the tropics; or (2) gross changes, when they occur, are differentially selected and confer an enhanced survival value in temperate areas. In attempting an evaluation of these two hypotheses it must be remembered that the behaviour and general biology of shieldbugs show that the tropics provide optimum conditions for the group, while the rich fauna suggests it is also the area of maximum speciation.

Dr. R. E. Blackith, of the Imperial College of Science and Technology, London, has kindly assisted me with the statistical analysis.

44 Abbey Road,

London, N.W.8. July 2.

${ }^{1}$ Manton, I., Symp. Soc. Exp. Biol., 7, 174 (1953).

${ }^{2}$ Schrader, F., and Hughes-Schrader, S., Chromosoma, 7, 469 (1956).

\section{Sexual Colour Differences in Caranx ignobilis (Forsk.)}

Caranx ignobilis (Forsk.), the largest of the IndoPacific carangids, is a valued food fish from the East African coast to the Hawaiian Islands. The biology of this fish is being studied by one of us (F. W.), and it has been found that maturity is reached between 500 and $650 \mathrm{~mm}$. standard length.

Routine observations on catches have shown that in specimens more than $500 \mathrm{~mm}$. long there is a difference in colour with sex. The male has a dusky to black body, head and fins. In the female the body and head are pale to silvery, except for slight duskiness on the back. Small black dots may or may not be present on the upper sides of the body. The fins are pale to dusky hyaline.

These colorations refer to living and freshly caught specimens, as some hours later both sexes become a uniform dusky grey.
Sex prediction tests were carried out on a sample of 88 specimens, standard length $500-1,150 \mathrm{~mm}$., and were correct in 90 per cent of cases. These colour differences develop with maturity. Most errors occurred in the size range $500-700 \mathrm{~mm}$., and may have been immature fish. With specimens more than $700 \mathrm{~mm}$. long prediction was nearly 100 per cent correct.

To our knowledge, these are the first recorded sexual colour differences in the Carangidae.

$$
\text { F. H. Talbot }
$$

East African Marine Fisheries

F. WILLIAMS

Research Organization, Zanzibar.

Aug. 2.

\section{Low Vitamin $B_{12}$ Concentrations in Serum in Fish Tapeworm Anæmia}

VARIOUs communications have been published on the microbiological vitamin $B_{12}$ activity in the sera from both healthy persons and patients suffering from various diseases. The concentration of vitamin $B_{12}$ varies fairly considerably in normal people. The lower limit is 70-100 $\mu \mu \mathrm{gm}$. and the upper 420 $900 \mu \mu \mathrm{gm}$. vitamin $\mathrm{B}_{12} / \mathrm{ml}$. of serum, depending on the microbiological method employed. Very low values, usually less than $50 \mu \mu \mathrm{gm} . / \mathrm{ml}$., have been found in pernicious anæmia ${ }^{1}$.

Megaloblastic anæmia in fish tapeworm (Diphyllobothrium latum) carriers shows a similar hæmatological picture to that of genuine pernicious anæmia. The essential factor in the origination of this anæmia would seem to be vitamin $\mathrm{B}_{12}$ deficiency caused by fish tapeworm which deprives the host organism of vitamin $\mathrm{B}_{12}{ }^{2}$. However, there is still a lack of data on the serum vitamin $\mathrm{B}_{12}$ concentration in this disease. We therefore determined the microbiological activity in the serum of eight patients with fish tapeworm anæmia. Twenty convalescents who had been treated for different diseases were examined as controls. Table 1. Microbiologroal B $_{12}$-VITAMTN ACTIVITy IN SFRA FROM
EIGHT PATIENTS WITH FISH TAPEWORM ANEMIA AND FROM TWENTY

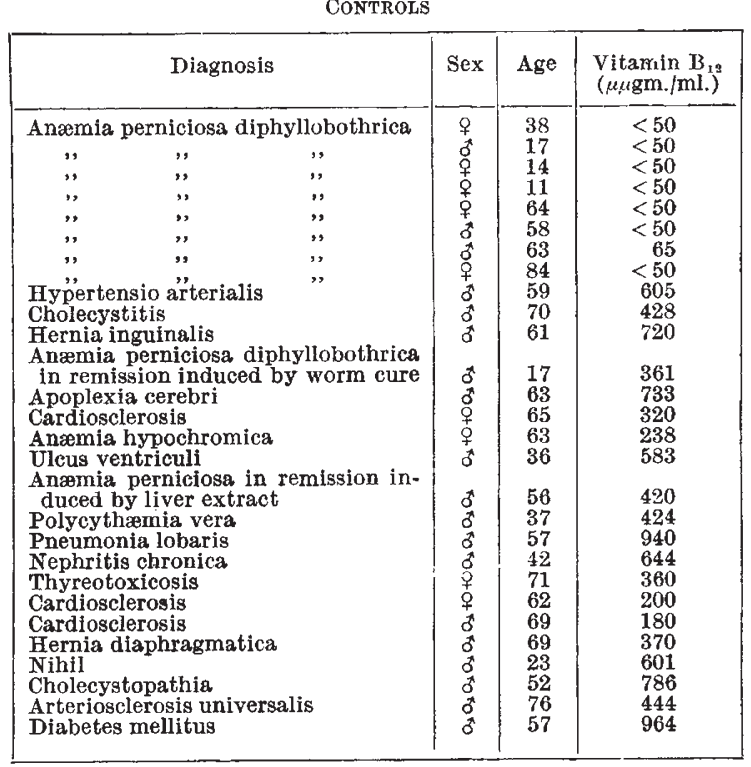

